\title{
EVOLUTIONARY STUDIES ON MANIOLA JURTINA: THE ISLES OF SCILLY, 1958-59
}

\author{
E. R. CREED, E. B. FORD and K. G. McWHIRTER \\ Genetics Laboratory, Department of Zoology, Oxford
}

Received 7.ii.64

\section{INTRODUCTION}

OuR evolutionary studies on Maniola jurtina in the Isles of Scilly have already been described up to 1957 (Dowdeswell et al., I960). Here and elsewhere we have made use of a quantitative character, the number of spots on the underside of the hindwings, for analysing the variability of this species and its response to differing conditions. The female spot-frequencies differ on five small islands, though remaining constant (with certain specific exceptions) on each, while they have been similar on three large ones, St Martin's, Tresco and St Mary's, with approximately equal values at $\mathrm{o}, \mathrm{I}$ and 2 spots. This latter stabilisation broke down for the first time in 1956 and 1957 on St Martin's and in 1957 on Tresco, but not on St Mary's where it persisted. Thus it was a matter of particular interest to determine what had happened in subsequent seasons. There were further reasons for this. We were anxious to know if any corresponding changes would affect the small islands or small isolated communities on the large ones. In one of these latter on Tresco, the population had maintained a constant value, unlike that in the Main Area of the island, from 1954-56, while in I 957 the butterfly had become nearly extinct in that particular locality. We were anxious to discover if the numbers would rise again and, if so, what frequency-distribution they would adopt. Answers to these questions are supplied in the present account, in which we describe the status of these Maniola jurtina populations in 1958 and I 959 .

Unfortunately we encountered great difficulties in the latter year. A long period of heat and drought had brought the butterfly out exceptionally early and the emergence was well advanced before we could be in the field in late July, owing to other commitments. We had then first to undertake the pressing work on the remarkable evolutionary situation on the Devon-Cornwall border, the results of which have already been published (Creed et al., 1962). Thus by the time two of us (E.R.C. and E.B.F.) could reach the Isles of Scilly in mid-August, $M$. jurtina was nearly over; normally the species is extremely abundant in the Isles at that date, somewhat later than on the Mainland. In consequence we were only able to obtain small samples in 1959, though spending long periods in collecting them. 


\section{THE LARGE ISLANDS}

\section{(i) St Martin's}

The Main Area. Up to and including 1955 the female spotdistribution was " flat-topped" in the Main Area of St Martin's, with approximately equal frequencies at 0 , I and 2 spots. In 1956 it changed for the first time, being distinctly unimodal at o spots and therefore passing to a lower spot-average $\left(0.95\right.$ in $195^{6}$ compared with $1 \cdot 19$ in 1955). However, it did not differ significantly from the "flat-topped" distribution existing up to $1955\left(\chi_{(3)}^{2}=3.99\right)$. The excess at o increased still further in 1957 (giving a spot-average of 0.93 ) and on a large sample ( 328 butterflies) it became significant compared with the

TABLE I

Spot-distributions in the Main Area of St Martin's, and in the three sub-areas into which this was divided, 1958. Female spot-average $=1 \cdot 32$

\begin{tabular}{|c|c|c|c|c|c|c|c|c|c|c|c|c|c|c|c|}
\hline \multirow{2}{*}{\multicolumn{2}{|c|}{ Area }} & \multicolumn{6}{|c|}{ Male spots } & \multirow{2}{*}{ Total } & \multicolumn{6}{|c|}{ Female spots } & \multirow{2}{*}{ Total } \\
\hline & & 0 & I & 2 & 3 & 4 & 5 & & $\circ$ & 1 & 2 & 3 & 4 & 5 & \\
\hline $\begin{array}{l}\text { B, Middle Town } \\
\text { C, The Plains } \\
\text { E, The Dunes }\end{array}$ & $:$ & $\bar{z}$ & $\frac{-}{1}$ & $\begin{array}{l}5 \\
9 \\
5\end{array}$ & $\begin{array}{l}8 \\
8 \\
4\end{array}$ & $\begin{array}{l}5 \\
5 \\
1\end{array}$ & $\frac{-}{I^{*}}$ & $\begin{array}{l}18 \\
23 \\
11\end{array}$ & $\begin{array}{l}17 \\
17 \\
12\end{array}$ & $\begin{array}{l}17 \\
15 \\
11\end{array}$ & $\begin{array}{l}19 \\
14 \\
10\end{array}$ & $\begin{array}{l}7 \\
4 \\
4\end{array}$ & $\begin{array}{r}- \\
4 \\
2\end{array}$ & - & $\begin{array}{l}60 \\
55 \\
39\end{array}$ \\
\hline Total . & . & - & I & 19 & 20 & II & I & $5^{2}$ & 46 & 43 & 43 & 15 & 6 & I & I 54 \\
\hline
\end{tabular}

* This specimen had 6 spots.

I950 to 1955 period $\left(\chi_{(3)}^{2}=8 \cdot 04\right)$. The male spotting was unimodal at 2 and its spot-average remained nearly stationary in $1956(2 \cdot 25$ compared with $2 \cdot 22$ the previous year) but slightly increased, to $2 \cdot 38$, in 1957. These facts have already been described (Dowdeswell, Ford and McWhirter, I96o).

In 1958, female spotting had returned to the "flat-topped" condition with a spot-average of $\mathrm{I} \cdot 32$ (table $\mathrm{I}$ ), but the slight excess at o still perceptible in that year became marked again in 1959, with a spot-average of 0.90 (table 2), though not to a significant extent compared with the stabilisation from 1950 to $1955\left(\chi_{(2)}^{2}=3 \cdot 47\right.$, $0.2>\mathbf{P}>0.1)$. The tendency for the males to become more spotted, observable in 1957, continued and increased in 1958, producing a spot-average of 2.87 . Unfortunately, for the reason already given (p. 47I), they were nearly over when we arrived in 1959 and only nine could be obtained in this area so that their spot-average $(2.56)$ is not significant (see tables I and 2).

As explained in our last paper, we subdivided the Main Area of St Martin's into three sub-areas in 1957 (areas A, B and C, see map, fig. I), to determine whether or not the spotting of a large island 
distribution were illusory as such, perhaps representing a combination of several different spot-frequencies. The latter possibility was disproved, the spotting in the three sub-areas being homogeneous. In I 958 we again subdivided the Main Area, using sub-areas B and C as before and a third, E, the sand dunes west of Middle Town where we had collected in the past but where we could obtain no specimens in 1957. The collections from these three sub-areas, which together constituted the main sample, proved to be remarkably homogeneous

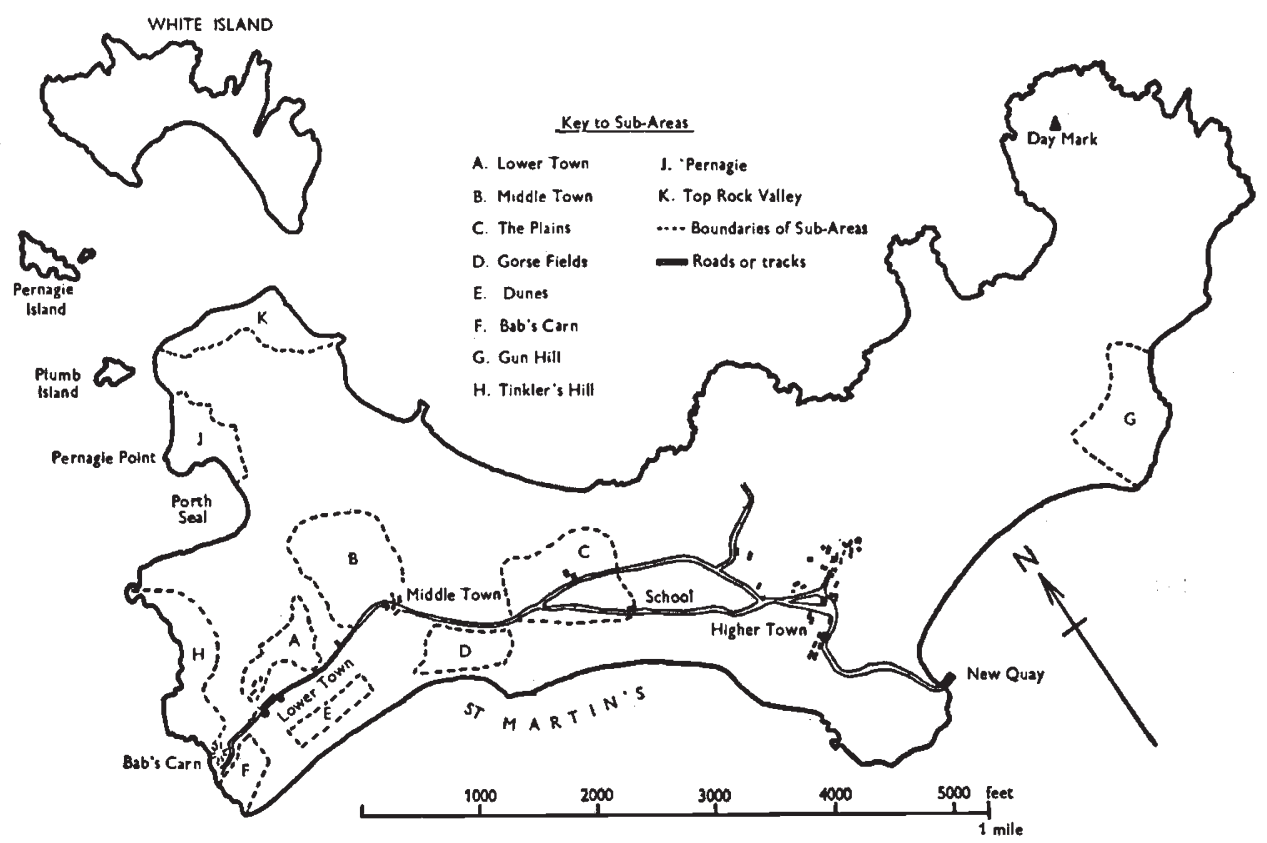

Fig. 1,-St Martin's and White Island, showing the boundaries of the collecting areas from which samples of $M$. jurtina have been taken. The samples recorded as St Martin's Main Area between $195^{\circ}$ and 1956 were collected in sub-areas B, C and D.

in $195^{8}$ (table I) for $\chi_{(B)}^{2}=\mathrm{I} \cdot 07$. The great deficiency of specimens in I959 made it impracticable to subdivide the Main Area into more than two components. These were $\mathbf{B}$ and $\mathbf{C}$ and the spotting in the female samples obtained (see table 2) was again homogeneous, $\chi_{(2)}^{2}=0.48$. Thus we have strong evidence that the female spot-distributions in the Main Area on St Martin's represent those of a single community and not the average of several distinct types. Neither in I 958 nor 1959 were the male samples sufficient to provide a valid comparison from the different sub-areas.

A further aspect of this analysis remains to be mentioned. In I957 we had collected from an additional sub-area A (see map, fig. I). Only io males could be obtained there, but it yielded 50 females which were, as we indicated, homogeneous with those from the main part of the island. Area A, situated above Lower Town, proved to be 
exceptional in $195^{8}$ in as much that it showed an intra-seasonal shift, the females being effectively unimodal at o on i7 August (like those in the Main Area in 1956-57) but with approximate equality at o, I and 2 spots on 21 August (like those in the Main Area in $195^{8}$ and

TABLE 2

Spot-distributions in the Main Area of St Martin's, and in the two sub-areas into which this was divided, 1959. Female spot-average $=0.90$

\begin{tabular}{|c|c|c|c|c|c|c|c|c|c|c|c|c|c|c|c|c|}
\hline \multirow{2}{*}{ Area } & & & \multicolumn{6}{|c|}{ Male spots } & \multirow{2}{*}{ Total } & \multicolumn{6}{|c|}{ Female spots } & \multirow{2}{*}{ Total } \\
\hline & & & 0 & I & 2 & 3 & 4 & 5 & & 0 & I & 2 & 3 & 4 & 5 & \\
\hline $\begin{array}{l}\text { B, Middle Town } \\
\text { C, The Plains }\end{array}$ & . & . & - & $\bar{I}$ & $\begin{array}{l}2 \\
3\end{array}$ & I & $\stackrel{1}{-}$ & - & $\begin{array}{l}4 \\
5\end{array}$ & $\begin{array}{l}16 \\
20\end{array}$ & $\begin{array}{l}10 \\
13\end{array}$ & $\begin{array}{r}8 \\
14\end{array}$ & $\begin{array}{l}1 \\
2\end{array}$ & 二 & - & $\begin{array}{l}35 \\
49\end{array}$ \\
\hline Total & . & 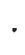 & - & I & 5 & I & I & I & 9 & 36 & 23 & 22 & 3 & - & - & 84 \\
\hline
\end{tabular}

in 1950 to 1955). On a third occasion, 30 August, only 13 females could be obtained (table 3). It seems in the circumstances best to treat area A separately, even though it had previously been included in the main area of the island. It is very close to area $\mathrm{H}$ (Tinkler's Hill), page 475, up a steep hill rising from the shore. Restricted as is

TABLE 3

Spot-frequencies in sub-area A, behind Lower Town, 1958

\begin{tabular}{|c|c|c|c|c|c|c|c|c|}
\hline \multirow{2}{*}{ Spots } & \multicolumn{3}{|c|}{ Male spotting } & \multirow{2}{*}{ Total } & \multicolumn{3}{|c|}{ Female spotting } & \multirow{2}{*}{ Total } \\
\hline & I7.viii & 21.viii & $3^{\text {o.viii }}$ & & 17.viii & 21.viii & $3^{\text {o.viii }}$ & \\
\hline 0 & - & - & - & o & 23 & 20 & 6 & 49 \\
\hline 1 & 3 & 3 & 2 & 8 & 13 & 18 & 3 & 34 \\
\hline 2 & 18 & 7 & I & 26 & II & 23 & 3 & 37 \\
\hline 3 & 8 & 4 & - & 12 & 3 & 3 & I & 7 \\
\hline 4 & 2 & 2 & - & 4 & - & - & - & - \\
\hline 5 & - & I & - & I & - & - & - & - \\
\hline Total & $3^{I}$ & I 7 & 3 & $5^{1}$ & 50 & 64 & 13 & 127 \\
\hline
\end{tabular}

Maniola jurtina to its localised habitats, it does nevertheless seem possible that individuals might sometimes be blown up from area $\mathrm{H}$ below (where the population was unimodal at o), so producing the heterogeneity of area A from one sampling to another. Alternatively, it may be that this small area was subject to powerful selection respectively for the two St Martin's stabilisations (p. 475) during the season. We could obtain no specimens there in 1959. 
Isolated Areas. We have pointed out in previous papers that owing to the nature of Maniola jurtina colonies, those occupying isolated areas on the large islands are capable of adjusting themselves to the special conditions of their habitats, much like those still more effectively cut off on small islands. Certain restricted localities of this kind occur near the coast of St Martin's (their positions are given in the map in our I96o paper). The populations inhabiting the majority of them conform to one or other of the two alternative stabilisations found in the Main Area of the island or else follow a low-spotted pattern in which the female spot-distribution is unimodal at o spots. In the Main Area a form with approximately equal frequencies at $\mathrm{O}, \mathrm{I}$ and 2 spots is the

TABLE 4

Female spot-frequencies in three isolated areas on St Martin's (see fig. I). Those for 1958 and 1959 have not previously been published

\begin{tabular}{|c|c|c|c|c|c|c|c|}
\hline Area & $\underset{1953}{\mathrm{H}}$ & $\underset{195^{8}}{\mathrm{H}}$ & $\underset{1953}{G}$ & Total & $\underset{195^{8}}{F}$ & $\underset{195^{8}}{G}$ & $\begin{array}{c}\mathrm{G} \\
1959\end{array}$ \\
\hline $\begin{array}{c}\text { Spots } \\
0 \\
1 \\
2 \\
3 \\
4 \\
5\end{array}$ & $\begin{array}{r}51 \\
21 \\
24 \\
7 \\
- \\
-\end{array}$ & $\begin{array}{r}44 \\
25 \\
24 \\
7 \\
\end{array}$ & $\begin{array}{r}55 \\
24 \\
27 \\
4 \\
\\
\end{array}$ & $\begin{array}{r}150 \\
70 \\
75 \\
18 \\
- \\
-\end{array}$ & $\begin{array}{r}25 \\
11 \\
7 \\
4 \\
1\end{array}$ & $\begin{array}{r}17 \\
21 \\
16 \\
2 \\
- \\
-\end{array}$ & $\begin{array}{r}26 \\
12 \\
5 \\
1 \\
-\end{array}$ \\
\hline Total & 103 & 100 & I 10 & 313 & 48 & 56 & 44 \\
\hline Spot-averages & 0.87 & 0.94 & 0.82 & $0 \cdot 88$ & 0.87 & $1 \cdot 05$ & 0.57 \\
\hline
\end{tabular}

normal one, as it is in the other large islands of Scilly, while that with a single mode at o (and equal, but lower, values at I and 2) has occurred only in two years, 1956 and 1957. The latter type is, however, more usual in these small marginal enclaves, which therefore tend to have lower spot-values than that characteristic of St Martin's in general. This particular low-spotted condition is illustrated by the first three columns in table 4 ; for it has been found in our two samples from area $\mathrm{H}$ and in that from area $\mathrm{G}$ in 1953. These three distributions are homogeneous $\left(\chi_{(\theta)}^{2}=2.34,0.9>\mathrm{P}>0.8\right)$ and do not differ significantly from that of the alternative stabilisation occurring in the Main Area in 1956 and $1957\left(\chi_{(3)}^{2}=3.82,0.3>P>0.2\right)$.

The flat-topped distribution has appeared twice in these small isolated localities. One of these was the population at Pernagie $(\mathrm{J})$ in $195^{8}$ (table 6), when it was homogeneous with that in the main part of the island the same year; for the comparison $\chi_{(3)}^{2}=5.4^{2}$ with $\mathrm{P}>0 \cdot \mathrm{I}$. Almost the whole of this $\chi^{2}, 4 \cdot 15$ indeed, is supplied by the individuals with 3 spots or over; the correspondence involving o to 2 spots, upon 
which in fact the comparison rests, is therefore a close one. As far as can be detected from the small sample it was possible to obtain (2I specimens), the Pernagie population had been unimodal at $o$ the previous year, 1957 .

TABLE 5

Male spot-values in isolated areas where available

\begin{tabular}{|c|c|c|c|c|}
\hline Area & $\underset{1958}{\mathbf{H}}$ & $\underset{195^{8}}{\mathbf{F}}$ & $\underset{195^{8}}{\mathrm{G}}$ & $\underset{\mathbf{r} 959}{\mathbf{G}}$ \\
\hline Spots & & & & \\
\hline 0 & I & - & - & - \\
\hline I & I & 1 & 2 & - \\
\hline 2 & $\begin{array}{l}18 \\
10\end{array}$ & $\begin{array}{l}3 \\
5\end{array}$ & 6 & ${ }^{2}$ \\
\hline $\begin{array}{l}3 \\
4\end{array}$ & 4 & - & 4 & I \\
\hline 5 & 2 & - & & - \\
\hline Total & 36 & 9 & 15 & 3 \\
\hline
\end{tabular}

TABLE 6

Female spot-frequencies at Pernagie (Area 7)

\begin{tabular}{|c|c|c|c|c|c|c|c|c|}
\hline Spots & 0 & I & 2 & 3 & 4 & 5 & Total & $\begin{array}{c}\text { Spot- } \\
\text { average }\end{array}$ \\
\hline rear & & & & & & & & \\
\hline $\begin{array}{l}1957 \\
1958\end{array}$ & $\begin{array}{l}13 \\
35\end{array}$ & $\begin{array}{r}2 \\
36\end{array}$ & $\begin{array}{r}2 \\
27\end{array}$ & 3 & I & 二 & 21 & 0.90 \\
\hline
\end{tabular}

TABLE 7

Spot-frequencies in the Top Rock Valley colony (Area K) formerly known as " the Coast opposite White Island". No males could be obtained in 1959

\begin{tabular}{|c|c|c|c|c|c|c|c|c|c|}
\hline Spots & Sex & 0 & 1 & 2 & 3 & 4 & 5 & 6 & Total \\
\hline rear & & & & & & & & & \\
$195^{8}$ & 0 & - & 2 & 17 & 7 & 4 & 3 & 1 & 34 \\
& + & 68 & 40 & 27 & 1 & 1 & - & - & 137 \\
1959 & + & 15 & 10 & 4 & 1 & - & - & - & 30 \\
\hline
\end{tabular}

The other isolated flat-topped distribution occurred at Gun Hill in $195^{8}$ (see table 4 , second column from right). This area seems indeed very susceptible to adjustment since it had passed the following year (r959) to the type of frequency-distribution descending steeply from o (table 4, right-hand column), like the Southern English (Creed et al., 1959). This latter type also characterises the populations in Top Rock Valley (K) opposite White Island (and in White Island itself, p. 48I) 
and that at Bab's Carn (F). Here we have evidence of the marked stability in spotting to which these small enclaves can attain when they have acquired a type well adjusted to them, for Area $\mathrm{K}$ has been constant ever since it was first studied in 1953 and it has remained so during the two years now under review (I $95^{8}$ and 1959), see table 7 .

TABLE 8

Female spot-distributions in isolated areas on St Martin's; the "alternative stabilisation" (area $G, 1953$, and area $H$ ) compared with the "Southern English" distribution (areas $F, K$ and $G$ in 1959)

\begin{tabular}{|c|c|c|}
\hline Spots & $\begin{array}{c}\text { Alternative } \\
\text { stabilisation }\end{array}$ & $\begin{array}{c}\text { Southern } \\
\text { English type }\end{array}$ \\
\cline { 2 - 3 } 0 & $\mathrm{I} 50$ & 292 \\
1 & 70 & 136 \\
2 & 75 & 77 \\
3 & 18 & 15 \\
4 & - & 3 \\
5 & - & 1 \\
\hline & $313(0 \cdot 88)$ & $524(0 \cdot 67)$ \\
\hline
\end{tabular}

We have thus sufficient numbers to determine whether the two spotdistributions unimodal at o found on St Martin's are in fact distinct: the "Southern English" type, descending steeply from o, and the alternative Main Area spotting with equal values at I and 2 (found also in some isolated enclaves). The two are compared in table 8 and they proved to be significantly distinct $\left(\chi_{(3)}^{2}=14.55\right.$ for which $\left.\mathrm{P}<0 \cdot 0 \mathrm{I}\right)$.

\section{(ii) Tresco}

The Main Area. Up to and including 1956, the female spotdistribution on Tresco had been of the "flat-topped" type with approximately equal values at $\mathrm{O}$, I and 2 spots, one characteristic also of the two other "large" islands that we have studied: St Martin's and St Mary's. In I 957, however, the Tresco population was much smaller than usual, though still amounting to several thousand, and it underwent a striking alteration to a lower female spot-frequency concurrently with a profound ecological change, one in which a dearth of grass and a dying back of bracken and bramble had resulted from a long and severe spring drought. In that year the selective elimination against females with 2 or more than 2 spots was $60 \cdot 6$ per cent. with 95 per cent. fiducial limits at 80.7 and 19.3 per cent. This, as we commented, represented "the strongest selection-pressure against a group of widespread phenotypes in a variable wild population that has ever been recorded ". These facts were fully reported by Dowdeswell et al. (1960). They are summarised here in table 9 in which the $195^{6}$ 
data are shown separately to indicate that no tendency to depart from the flat-topped distribution was perceptible in that year.

It was obviously a matter of much interest to obtain information on the ecology and Maniola population in the years immediately succeeding. This we were able to do, and the spot-frequencies for $195^{8}$ and I959 are added to table 9.

Following a normal season, the vegetation on Tresco had largely recovered in $195^{8}$. Maniola jurtina had again become common that year but its female spotting did not return to normal. On the contrary, it took up a new value with a mode at I. This is a quite

TABLE 9

Tresco, Main Area spot-frequencies in $195^{8}$ and 1959 , being new data. Those for previous years, already published, are given in a form useful for comparison. (* Including one specimen at 6 spots)

\begin{tabular}{|c|c|c|c|c|c|c|c|c|c|}
\hline \multirow{2}{*}{ Spots } & \multicolumn{4}{|c|}{ Males } & \multirow{2}{*}{$1950-55$} & \multicolumn{4}{|c|}{ Females } \\
\hline & I 956 & I 957 & 1958 & I959 & & I956 & I 957 & $195^{8}$ & 1959 \\
\hline $\begin{array}{l}0 \\
1 \\
2 \\
3 \\
4 \\
5\end{array}$ & $\begin{array}{r}1 \\
5 \\
47 \\
21 \\
1 \\
2\end{array}$ & $\begin{array}{l}\frac{1}{6} \\
5 \\
3 \\
\end{array}$ & $\begin{array}{c}- \\
1 \\
20 \\
12 \\
6 \\
5^{*}\end{array}$ & $\begin{array}{r}- \\
I \\
I \\
3 \\
-\end{array}$ & $\begin{array}{r}140 \\
136 \\
151 \\
26 \\
8 \\
1\end{array}$ & $\begin{array}{r}34 \\
30 \\
34 \\
5 \\
2 \\
\end{array}$ & $\begin{array}{r}21 \\
17 \\
8 \\
2 \\
-\end{array}$ & $\begin{array}{r}23 \\
41 \\
32 \\
13 \\
6 \\
-\end{array}$ & $\begin{array}{r}\text { Io } \\
\text { I0 } \\
8 \\
\text { I } \\
- \\
-\end{array}$ \\
\hline & 77 & 15 & 44 & 5 & 462 & 105 & $4^{8}$ & I I5 & 29 \\
\hline
\end{tabular}

exceptional type of distribution, almost unknown heretofore. It probably indicates a situation when the spot-frequencies are changing to another value: we have indeed encountered abnormal spotting in such conditions elsewhere, though not the type with a mode at I. That suggestion is supported by the fact that the population seems to have returned to its normal flat-topped distribution the year following (1959) as far as our limited data are able to show (see table 9). It was indeed with the utmost difficulty and many hours of work that we were then able to raise our sample to the small total of 29 females, collecting, as we were, when the emergence was nearly over.

The Farm Area. This enclave, of $200 \times 70$ yards, is isolated from the Main Area of Tresco. It ecology is exceptional, since it supports an unusual flora consisting partly of escapes from cultivation. In spite of its small size, we were able to obtain adequate collections there in the three years 1954-56. These spot-frequencies are homogeneous and sharply unimodal at 2, a type distinct from that characterising the Main Area of the island (Dowdeswell et al., I96o, see table I 2).

The drought of 1957 which had materially reduced the numbers of Maniola jurtina in the Main Area of Tresco had almost depopulated the 
Farm Area since this locality has a very sandy soil which much accentuated the effect of the prolonged dry weather. In fact, a search involving four net-hours at the height of the season only produced four butterflies, all females, which in so small an enclave may well have represented the entire flying population at the time.

Here indeed was a situation in which the operation of random genetic drift or of the founder principle (the effect of an occasional wanderer from the Main Area) might be expected to be decisive in controlling the evolution of the colony in the Farm Area when its numbers rose again. They did so the following year (I958), for the vegetation had by then largely recovered; not indeed to as high a value as before, but to a level which enabled us to obtain 16 males and

TABLE 10

Tresco Farm Area spot-frequencies in 1958 and 1959 , being new data. Earlier years are given for comparison. One specimen in 1957 was unscorable

\begin{tabular}{|c|c|c|c|c|c|}
\hline \multirow{2}{*}{ Spots } & \multirow{2}{*}{$\begin{array}{c}\text { Males } \\
195^{8}\end{array}$} & \multicolumn{4}{|c|}{ Females } \\
\hline & & $1954-56$ & 1957 & $195^{8}$ & 1959 \\
\hline o & - & 34 & 2 & I & - \\
\hline I & - & 33 & - & 5 & I \\
\hline 2 & 6 & 73 & I & 12 & I \\
\hline 3 & 6 & 15 & - & 2 & I \\
\hline \multirow{2}{*}{5} & 2 & 5 & I & $\bar{z}$ & - \\
\hline & 16 & 160 & $3+I$ & 20 & 3 \\
\hline
\end{tabular}

20 females in five net-hours. The daily flying population at the time was probably between 50 and 100 imagines. Yet we found that the population, thus reconstructed after extreme numerical reduction, had returned to the same exceptional spot-frequency which had characterised it previously: one in which the females were unimodal at 2 (table 1o). The comparison between the female population of I $95^{8}$ and that during the period I $954-56$, before the numerical collapse of ${ }_{1957}$, is given by $\chi_{(1)}^{2}=0.6 \mathrm{I}$ with $\mathbf{P}>0.3$, using Yates' correction. It will be noticed that this return to a previous value is not explicable in terms of migration; since the spot-distribution in the Main Area of the island, whence any migrants must come, was known throughout the whole period and it was never of the kind found in the Farm Area. Extremely powerful selection in favour of a type adapted to the highly abnormal conditions of that habitat is indicated by these facts.

The hot summer of I 959 had evidently brought the species out earlier in the Farm Area as it had done elsewhere. Consequently only three worn specimens could be obtained there in five net-hours that year (table Io). 


\section{(iii) St Mary's}

The females in the St Mary's population have maintained the approximately flat-topped distribution, characteristic of the large islands in general, throughout the whole period we have collected there from 195 I to 1959 , seven years in all (table II). The numbers in the latter season were small for the reason already given, but they do not differ from the situation which had previously persisted. Thus this flat-topped stabilisation has been maintained during the years in which the St Martin's and Tresco populations departed from it (1956 and

TABLE II

St Mary's spot-frequencies in $195^{8}$ and 1959 are new data. Earlier years are given for comparison

\begin{tabular}{|c|c|c|c|c|c|c|c|}
\hline \multirow{2}{*}{ Spots } & \multicolumn{3}{|c|}{ Males } & \multicolumn{3}{|c|}{ Females } & \multirow{2}{*}{ Total } \\
\hline & I957 & I 958 & ז959 & $\begin{array}{l}\text { up to } \\
\text { I } 957\end{array}$ & $195^{8}$ & 1959 & \\
\hline o & - & - & - & I 24 & & I 2 & \\
\hline I & - & I & I & 102 & 28 & 6 & I 36 \\
\hline 2 & 4 & II & I & 122 & 33 & 9 & 164 \\
\hline 3 & 4 & I3 & 2 & $3^{6}$ & 16 & I & 53 \\
\hline 4 & 2 & 5 & I & 15 & 4 & I & 20 \\
\hline \multirow[t]{2}{*}{5} & 一 & 2 & - & I & I & - & 2 \\
\hline & so & 32 & 5 & 400 & 117 & 29 & 546 \\
\hline
\end{tabular}

I 957 on St Martin's, 1957 and $195^{8}$ on Tresco). It is, in fact, slightly deficient at I spot, but not significantly so $\left(\chi_{(2)}^{2}=2 \cdot 26, \mathrm{P}>0 \cdot 2\right)$. This is, in any event, a second order difference, the reality of which might well be established with larger samples.

\section{(iv) Conclusions on the large islands}

We have shown that in Scilly the three large island populations which we have studied are in general all stabilised in a similar way, with approximately equal values at $\mathrm{O}, \mathrm{I}$ and 2 spots in the females (from which they may be displaced by exceptional climatic conditions but to which they have always returned), while those on five small islands take widely differing, but constant, values. Our results indicate that this situation is due to selection. That is to say, the populations on the small islands can be adjusted to the special conditions of each habitat while those flying in extensive and diversified areas on the large ones can adjust only to the average of the conditions found there, and such averages will tend to be similar.

However, attempts have been made to interpret this situation differently: the similarity of the large island populations and the 
dissimilarity of those inhabiting the small islands has been ascribed to the "founder principle" by Dobzhansky and Pavlovsky (1957) and to " intermittent drift" by Waddington (I957). It is likely that neither suggestion would have been made had these authors known that a large island population can, as an exceptional occurrence, change in a single generation to an entirely distinct spot-distribution, the numbers remaining large (some thousands) throughout. Thus the derivation of the large island communities from an original Scillonian type, conferring similarity upon them, as required by the theories of Dobzhansky and Pavlovsky and of Waddington, is scarcely a tenable concept. Moreover, consequent upon an extreme ecological change, due to the removal of a long-established herd of cattle, we had already witnessed on Tean a readjustment to a new spot-value as different from the old as that distinguishing one small island type from another (Dowdeswell et al., 1957). The proof therefore is complete that neither intermittent drift nor the founder principle is responsible for the types of spotting which distinguish $M$. jurtina in the various Isles of Scilly. It is to be noticed that the spot-frequency has remained constant on the most diversified of the large islands, St Mary's, in accord with the selective interpretation adopted here.

\section{THE SMALL ISLANDS}

(i) White Island

This island, lying off the north-west coast of St Martin's (see map, fig. I), consists of two rocky land masses rising to over $5^{\circ}$ feet above sea level and joined by a low-lying isthmus. One of the most obvious changes when we visited the island in $195^{8}$ was that the sea had washed across this strip in the winter storms killing all the grass and leaving a band about $30 \mathrm{~m}$. wide occupied only by a few salt-loving plants. As it was felt that this might now constitute an effective barrier to $M$. jurtina, we decided to collect the two halves of the island separately.

The results of both years' collections are given in table 12 together with the combined figures for 1953-57 which we have previously shown to be homogeneous. Although the north and south female samples in $195^{8}$ are not significantly different from one another, the distinction between the latter and the combined samples for previous years is measured by $\chi_{(2)}^{2}=16.32$ giving $\mathrm{P}<0.001$.

The overall increase in spotting on White Island is reflected to a far greater extent in the males, the mode being at three spots in the south and four in the north; the two male samples are significantly different $\left(\chi_{(2)}^{2}=7.70\right.$ giving $\left.0.05>P>0.02\right)$. In view of these changes we decided against continuing the experiment of transferring females across to Top Rock Valley (see p. 348 and Dowdeswell et al., 1960).

In 1959 the mode at $o$ of the females from the northern part was more pronounced, the sample being very similar to the combined White Island figures of $1953-57$. In the south only seven females were caught, 
TABLE 12

Spot-distribution in Maniola jurtina on White Island

\begin{tabular}{|c|c|c|c|c|c|c|c|c|c|}
\hline \multirow{2}{*}{ Females } & \multirow{2}{*}{ Year } & \multicolumn{6}{|c|}{ Spots } & \multirow{2}{*}{ Total } & \multirow{2}{*}{$\begin{array}{l}\text { Spot- } \\
\text { average }\end{array}$} \\
\hline & & o & 1 & 2 & 3 & 4 & 5 & & \\
\hline North & $\begin{array}{c}1953-7 \\
1958 \\
1959\end{array}$ & $\begin{array}{r}209 \\
12 \\
28\end{array}$ & $\begin{array}{r}108 \\
11 \\
11\end{array}$ & $\begin{array}{r}76 \\
7 \\
7\end{array}$ & 1 & $\frac{-}{2}$ & I & $\begin{array}{r}395 \\
33 \\
46\end{array}$ & $\begin{array}{l}0.68 \\
1.03 \\
0.54\end{array}$ \\
\hline South & $\begin{array}{l}\text { ז } 958 \\
\text { เ } 959\end{array}$ & 17 & $\begin{array}{r}20 \\
4\end{array}$ & $\begin{array}{r}19 \\
3\end{array}$ & 3 & 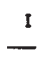 & 1 & $\begin{array}{r}6 t \\
7\end{array}$ & $\begin{array}{l}1 \cdot 25 \\
1 \cdot 43\end{array}$ \\
\hline $\begin{array}{l}\quad \text { Males } \\
\text { North } \\
\text { South }\end{array}$ & $\begin{array}{l}1957 \\
195^{8} \\
195^{8}\end{array}$ & $\frac{1}{1}$ & $\begin{array}{l}4 \\
2 \\
3\end{array}$ & $\begin{array}{r}\mathrm{I} \mathrm{I} \\
\mathrm{I} \\
7\end{array}$ & $\begin{array}{r}2 \\
7 \\
10\end{array}$ & $\begin{array}{l}\text { I } \\
9 \\
3\end{array}$ & $\begin{array}{l}1 \\
3 \\
2\end{array}$ & $\begin{array}{l}20 \\
22 \\
26\end{array}$ & $\begin{array}{l}2.05 \\
3.50 \\
2.65\end{array}$ \\
\hline
\end{tabular}

but when compared with the sample from the north using Armsen's $2 \times 2$ contingency tables (1955) the difference is found to be significant at the I per cent. level. Only one male was caught in each area in 1959.

\section{(ii) St Heien's}

St Helen's had previously been visited in I95I and 1953 (Dowdeswell and Ford, I955), the female samples for the two years being homogeneous when compared in a $2 \times n$ table $\left(\chi_{(3)}^{2}=5 \cdot 80\right.$; $P=0 \cdot 1$ to $0 \cdot 2$ ). We collected 52 females in $195^{8}$ and as will be seen from table 13 there has been a decrease in spotting as indicated by the

TABLE 13

Spot-distribution in female Maniola jurtina on St Helen's

\begin{tabular}{|c|c|c|c|c|c|c|c|c|}
\hline \multirow{2}{*}{ Year } & \multicolumn{6}{|c|}{ Spots } & \multirow{2}{*}{ Total } & \multirow{2}{*}{$\begin{array}{l}\text { Spot- } \\
\text { average }\end{array}$} \\
\hline & 0 & 1 & 2 & 3 & 4 & 5 & & \\
\hline $\begin{array}{l}1951 \\
1953\end{array}$ & $\begin{array}{l}26 \\
46\end{array}$ & $\begin{array}{l}4^{1} \\
53\end{array}$ & $\begin{array}{l}64 \\
65\end{array}$ & $\begin{array}{l}18 \\
14\end{array}$ & $\begin{array}{l}3 \\
2\end{array}$ & $\underline{I}$ & $\begin{array}{l}153 \\
180\end{array}$ & $\begin{array}{l}\text { I } \cdot 57 \\
\text { I } 29\end{array}$ \\
\hline 1958 & 16 & 14 & 19 & 2 & I & - & 52 & $1 \cdot 19$ \\
\hline
\end{tabular}

average spot numbers. This does not affect the homogeneity in a $3 \times n$ table of general contingency, but when the $195^{8}$ sample is added to that for 1953 and compared with I95I a formally significant difference is found with $\chi_{(3)}^{2}=8.04,0.05>\mathrm{P}>0.02$. At no time have sufficient males been caught to make a comparison possible. 


\section{(iii) Great Ganilly}

Previously we have treated the butterflies on Great Ganilly as consisting of a single population. There is, however, a strip of less suitable ground, $50 \mathrm{~m}$. wide, on the low-lying isthmus which joins the two halves of this island and in view of the results obtained on White Island (see p. 48I) we collected the north and south parts separately in I959. In $195^{8}$ we had obtained one combined sample and one from the southern half only. The results are summarised in table 14. When the two female samples for 1959 are compared the difference is measured

TABLE I4

Spot-distribution in Maniola jurtina on Great Ganilly

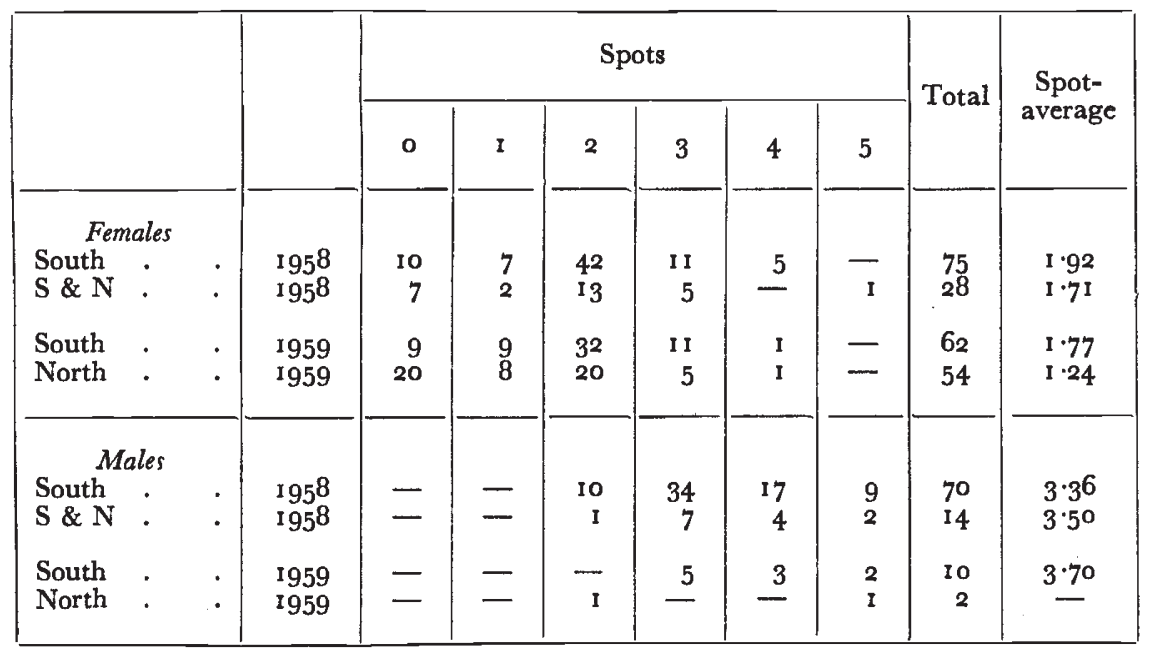

by $\chi_{(3)}^{2}=8.48 ; 0.05>\mathrm{P}>0.02$. It was, therefore, necessary to reconsider the previous years' results.

A progressive change in the spot distributions had been observed on Great Ganilly between I95I and 1955; this was more or less reversed in 1956 (Dowdeswell et al., 1960). At the time we were unable to ascribe any causes to this, but in view of the result of 1959 it seems likely that a large part of the variation can be accounted for on the basis of non-random collecting. Different proportions of the samples coming from the north and south each year would cause apparent fluctuations in spot-distribution between limits set by the two component halves. This will not, however, account for the increase in male spotting which has persisted since 1956. Previously the mode of the male spot-distribution had been at 2 spots; since then the mode has been at 3 or more spots. We have shown (Dowdeswell et al., 1960) that the $195 \mathrm{I}$ and 1955 figures for the males are homogeneous with $\chi_{(2)}^{2}$ $=2.80 ; 0.3>\mathbf{P}>0.2$. The samples for $195^{6}$ to 1959 also prove to be homogeneous with $\chi_{(3)}^{2}=3 \cdot 82 ; 0.3>P>0.2$. When the two sets of 
samples are each combined and compared the difference is given by $\chi_{(2)}^{2}=39 \cdot 79$. This change occurred at a time when the population was large, probably of the order of Io,ooo insects, and it is therefore unfortunate that in the circumstances the figures for the females cannot be more fully analysed.

\section{DISCUSSION}

When we first observed that isolation of populations of $M$. jurtina could afford them an opportunity of genetic adjustment to varying selective forces, we took the cautious view that such distinctions might occur when the populations were entirely separated by about 150 yards of terrain over which the imagines were reluctant to fly (Dowdeswell and Ford, 1955). Different equilibria of gene frequencies could be sustained by comparatively slight divergences in constant selective forces operating in each contrasted habitat, provided that enough time had elapsed for such equilibria to become established. Important ecological changes, however, such as those occasioned by the removal of cattle from the island of Tean could evoke rapid adjustment in the butterfly population (Dowdeswell, Ford and McWhirter, 1957).

Subsequently, however, we obtained evidence that the selective forces acting on the genes controlling spotting in the butterfly must be very strong indeed, and, though usually constant, could themselves vary sharply from time to time. Further, we found that even partial isolation of populations in areas of variable selection such as Scilly is enough to allow this strong selection to maintain sharply distinct population structures. This has become clear in the Farm Area of Tresco and in the various coastal enclaves on St Martin's, none of which is so isolated that occasional immigrants do not enter from neighbouring areas, yet all of which maintain significantly distinct populations. In the cases at least of the Farm Area of Tresco and of Top Rock Valley on St Martin's these specially adapted populations have not yet been found to vary from year to year despite great fluctuations in the effective breeding numbers.

After our discovery on the Mainland (Creed et al., r959) that the switch from the South English pattern occurs at a very sharp boundary near the Devon-Cornwall border and that there need be no isolation between populations responding to the two types of selection, we thought it important to analyse the Scilly populations even more minutely according to geographic sub-areas. The results have been rewarding in that analysis of the St Martin's populations shows that there is, as we had suspected, a large "Main Area" composed of homogeneous sub-areas in which no isolated pockets could be detected; where, however, we had seen some possibility of partial isolation, perhaps 20 yards of unfavourable terrain, we have in fact demonstrated significantly distinct peripheral populations. In White Island we seem actually to have witnessed the division of a homogeneous population as the incursion of the sea widened a strip of ground, which the insect could 
not inhabit, beyond the critical size (here perhaps 25 to 30 yards). This division seems to have induced a short period of violent disturbance of the normal correlations between male and female spotting, after which one side (the Northern part with the larger current population) reverted to the former, less highly spotted pattern, while the other side seems to be establishing a new, more highly spotted population. A similar division had probably already taken place on Great Ganilly before we became aware of the subtly small amount of isolation needed to allow strong selective pressures to mould distinct population types of this insect at each end of the island.

If then the selective forces are strong ones, the possibility must always exist that large populations, irrespective of their size, could undergo sudden and substantial transformations. Such have now been observed both on the Mainland and on St Martin's and Tresco in Scilly. Further, Dowdeswell (I96 I and I962) has presented evidence that a widely occurring Braconid, Apanteles tetricus, and perhaps a bacterial pathogen are two of the selective agents acting on the larval phase of $M$. jurtina.

It would be strange if similar patterns had not been observed in such other wild organisms as have been adequately and quantitatively studied. Bradshaw (1952, I959 and 1960) has carried out an intensive survey of morphological and physiological differences in populations of a common grass, Agrostis tenuis Sibth. This outbreeding plant develops populations which vary greatly in habit and in ability to resist what are normally toxic levels of lead and zinc in the soil. These differences were found to be reproduced in seedlings bred from wild samples. Bradshaw remarks (I959, at p. 223) " Providing differences in natural selection are great enough, they can maintain differences between populations between which there is a considerable gene flow." In this earlier work Bradshaw found that $A$. tenuis exhibited differences between populations separated by only I 50 feet ( $50 \mathrm{~m}$. approximately). Later Bradshaw and Aston ( 1963 ) observed that populations of different genetic types could be found within a few feet of each other. Sympatric evolution is leading to the development of highly varied and specialised populations in these grasses.

Intensive studies of selection in the snails Cepaa nemoralis and $C$. hortensis have been carried out for some years by A. J. Cain and his colleagues. In a recent paper on area effects in Cepaa, Gain and Currey ( 1963 , at pp. I5-I6) report a remarkably steep phenotype cline in nemoralis specimens. These switch from 80 to 12 per cent. in favour of yellow shells to 13 to 73 per cent. in favour of brown shells within I $30 \mathrm{~m}$. The authors believe that these populations are in no way isolated from each other except by distance. Although in many areas of mixed background, selection has been shown to be maintained by predation (Cain and Sheppard, I950 and 1954), there is in this case no obvious clue to any selective forces which might produce the cline.

These general conclusions are in accord with, and are strongly 
supported by, the work of Thoday and Boam (I959) when testing experimentally the deductions reached by Mather (1955) in his analysis of disruptive selection. He points out that this process becomes effective when two or more optima are favoured in a population. That situation must lead, as he indicates, either to genetic isolation or, alternatively, to polymorphism. Using Drosophila melanogaster, Thoday and Boam were able to show that lines selected in different directions diverged significantly even though there was a 50 per cent. gene-flow between them.

It is reasonable to conclude that the apparent stability of species or of geographically defined breeding groups is often, or even normally, the resultant of a large number of strong selective forces. A complete analysis of these would involve one in the complex and almost impossible task of a complete investigation into the whole nexus of ecological factors acting directly or indirectly on the subject species. Identification of the major forces with respect to a particular character is, however, a reasonable objective and would permit the observer to predict change in the gene frequencies of a suitable wild population.

Ability to predict evolutionary trends from measurements of local, temporal or qualitative changes in selective forces is the next stage to which combined ecological and genetical studies should lead us. More rapid solutions of problems in the breeding, choice and adaptation of domestic animals and plants should eventually be obtained by following this line of thought. From many points of view, and especially now that difficulties in experimental breeding and rearing are being overcome, M. jurtina is proving a useful model for objectives of this kind.

\section{SUMMARY}

I. The distribution of spot numbers on the underside of the hindwing of the butterfly, Maniola jurtina, was investigated in the two years under review.

2. In $195^{8}$ the spot-numbers in the main area of St Martin's returned to the "flat-topped" condition (with equal numbers at o, I and 2 spots) existing prior to 1956 and in general characteristic of the three large islands; this distribution was retained in I959, though there was a slight excess of individuals with no spots.

3. In $195^{8}$ the main area of Tresco showed an unusual spotdistribution with a mode at I ; in I959 it reverted to "flat-topped".

4. The population in the Farm Area of Tresco, after an extreme reduction in size in 1957 , had largely recovered in 1958 . In spite of the opportunity for random genetic drift, the spot-distribution was the same as before the drop in numbers, demonstrating that it is controlled by powerful selection.

5. St Mary's has retained the flat-topped distribution unchanged since it was first visited.

6. The isolated areas on St. Martin's may adopt one of three well 
defined stablisations; they may be flat-topped, or have a mode at o spots with either equal numbers at I and 2, or with progressively fewer individuals in each spot-number class.

7. The collecting area on White Island is becoming divided into two halves by the effect of salt spray on the vegetation at the narrowest point of the island. The males, but not the females, from the two halves differed significantly in $195^{8}$; the females were significantly different on the two halves in I959, but only two males were caught.

8. The females on St Helen's show a slight decrease in spotting when compared with previous years.

9. Collections of females from the two halves of Great Ganilly were found to differ significantly in respect of spot-numbers; the area separating the two halves is in many ways similar to the break on White Island. The collection of different proportions of the sample from the two halves in previous years may account partly for the apparent changes in spot-distribution of the females. It cannot account for the progressive increase observed in male spotting.

10. These sharp geographical changes in spot-distribution are discussed in relation to the similar phenomena found on the mainland of Britain in this insect and in other species.

II. The similarity of spotting on the large islands and its dissimilarity from one to another of the small ones has been attributed by Dobzhansky and Pavlovsky to the "founder principle" and by Waddington to "intermittent drift". It is likely that neither suggestion would have been made had the authors known that the large- as well as the small-island colonies can, in exceptional circumstances, change in a single generation to entirely distinct spot-values, without marked reduction in population size.

Acknowledgments.-We are most grateful to the Nuffield Foundation for their financial support of the Genetic Laboratories, Department of Zoology, Oxford, which has enabled us to carry out our general programme of research on ecological genetics. Hearing of its progress, the Department of Scientific and Industrial Research most generously provided us with special funds to enable the studies on Maniola jurtina to be conducted on a far more extensive scale than would otherwise have been possible. The results of this paper are largely due to their generosity. Lt.-Com. T. Dorrien-Smith most kindly gave us permission to collect Lepidoptera on Tresco and on the uninhabited Isles of Scilly. Two of us wish to make most grateful acknowledgment of grants: E.R.G. to the Nature Gonservancy, and K. G. McW. to the Medical Research Council.

\section{REFERENCES}

ARMSEN, P. 1955. A new form of table for significance tests in a $2 \times 2$ contingency table. Biometrika, 42, 494-5II.

BRADShaw, A. D. I952. Populations of Agrostis tenuis resistant to lead and zinc poisoning. Nature, Lond., 169 , 1098 .

BRADShaW, A. D. I959. Population differentiation in Agrostis tenuis Sibth. I. Morphological differentiation. New Phytol., 58, 208-227.

Bradshaw, A. D. I96o. Population differentiation in Agrostis tenuis Sibth. III. Populations in varied environments. New Phytol., 59, 92-103. 
BRADShaW, A. D., AND ASTON, J. L. 1963. Evolution in closely adjacent plant populations. Heredity, $18, \mathrm{I} 25$.

Cain, A. J., ANd currey, J. D. 1962. Area effects in Cepæa. Phil. Trans. Roy. Soc., B, $246, \mathrm{I}-8 \mathrm{r}$.

CAIN, A. J., AND SHEPPARD, P. M. 1950. Selection in the polymorphic land snail Cepca nemoralis. Heredity, 4, 275-294.

CAIN, A. J., AND Sheppard, P. M. 1954. Natural selection in Cepra. Genetics, 39, 89-I I 6.

CREED, E. R., DOWDESWELl, W. H., FORD, E. B., AND MGWHIRTER, K. G. 1959. Evolutionary studies on Maniola jurtina: the English Mainland, 1956-57. Heredity, I3, 363-39 I.

GREED, E. R., DOWDESWELL, W. H., FORD, E. B., AND MCWHIRTER, K. G. I962. Evolutionary studies on the English Mainland, 1958-6o. Heredity, 17, 237-265. DOBZHANSKY, TH., AND PAVLOVSKY, O. 1957. An experimental study of interaction between genetic drift and natural selection. Evolution, II, 3 II-3I9.

DOWDESWELL, W. H. I 96 I. Experimental studies on natural selection in the butterfly, Maniola jurtina. Heredity, $16,39-52$.

DOWDESWELL, W. H. I962. A further study of the butterfly Maniola jurtina in relation to natural selection by Apanteles tetricus. Heredity, $17,5^{1}$ 3-523.

DOWDESWELL, W. H., AND FORD, E. B. 1953. The influence of isolation on variability in the butterfly Maniola jurtina L. Symposia Soc. exp. Biol., 7, 254-273.

DOWDESWELL, W. H., AND FORD, E. B. 1955. Ecological genetics of Maniola jurtina L. on the Isles of Scilly. Heredity, 9, 265-272.

DOWDESWELl, W. H., FORD, E. B., AND MCWHIRTER, K. G. 1957. Further studies on isolation in the butterfly Maniola jurtina L. Heredity, $I I, 5 \mathrm{I}-65$.

DOWDESWELL, W. H., FORD, E. B., AND MCWHIRTER, K. G. I96o. Further studies on the evolution of Maniola jurtina in the Isles of Scilly. Heredity, 14, 333-364.

Mather, K. 1955. Polymorphism as an outcome of disruptive selection. Evolution, 9, 52-6I.

thoday, J. M., AND boam, т. в. 1959. Effects of disruptive selection. 2. Polymorphism and divergence without isolation. Heredity, 13, 205-218.

waddington, a. H. 1957. The strategy of the genes. (Pp. 86 and 87.) George Allen \& Unwin Ltd. 